\title{
PENGEMBANGAN BUKU AJAR STATISTIKA DENGAN SOFTWARE R UNTUK MENINGKATKAN MOTIVASI BELAJAR DAN PEMAHAMAN
}

\author{
Muhammad Taqwa ${ }^{1 *}$, Akbar Taufik ${ }^{2}$ \\ ${ }^{1}$ STKIP Andi Matappa \\ ${ }^{2}$ Universitas Pancasakti \\ * Corresponding Author. Email: muh.taqwa@stkip-andi-matappa.ac.id \\ Received: 01 Juli 2019; Revised: 5 Agustus 2019; Accepted: 30 Agustus 2019
}

\begin{abstract}
ABSTRAK
Penelitian ini merupakan penelitian pengembangan yang bertujuan untuk mengembangkan buku ajar yang memenuhi kriteria valid dan praktis. Buku ajar ini sebagai penunjang perkuliahan statistika guna meningkatkan motivasi belajar dan pemahaman konsep statistika sehingga mahasiswa memiliki ketrampilan analisis data dengan software $R$ secara mandiri. Prosedur pengembangan buku ajar ini terdiri atas 4 tahap yaitu : pendefinisian, perancangan, pengembangan dan penyebaran.. Materi buku ajar sesuai dengan rencana pembelajaran statistik yang ditampilkan dengan contoh dan software dengan R. Hasil penelitian yaitu (1) penilaian reviewer diperoleh skor validitas isi buku ajar adalah 0,81 yang berarti bahwa validitas isi buku ajar termasuk kategori tinggi dengan reliabilitas 0,89, sehingga buku ajar layak untuk digunakan sebagai alat penunjang kegiatan pembelajaran statistika matematika;(2) Buku ajar ini memiliki kriteria sangat praktis. Hal ini di jelaskan pada hasil uji kepraktisan oleh mahasiswa sehingga buku ajar layak digunakan pada perkuliahan statistika matematika; (3) Tidak ada peningkatan motivasi belajar mahasiswa pada matakuliah statistika matematika dengan perlakuan diajar menggunakan software $R$ dan buku ajar statistika dengan $R$. Hal ini didukung oleh rata-rata ngain item motivasi belajar mahasiswa diperoleh yaitu -0,07 berada pada kategori rendah; (4) Tidak ada peningkatan pemahaman konsep mahasiswa pada matakuliah statistika matematika dengan perlakuan diajar menggunakan software $R$ dan buku ajar statistika dengan $R$. Hal ini didukung oleh ratarata ngain item pemahaman konsep mahasiswa diperoleh yaitu 0,25 berada pada kategori rendah.
\end{abstract}

Kata Kunci: Buku; R; Motivasi Belajar; Pemahaman

How to Cite: Taqwa, M,. \& Taufik, A.. (2019). Pengembangan Buku Ajar Statistika dengan Software R untuk Meningkatkan Motivasi Belajar dan Pemahaman. Histogram: Jurnal Pendidikan Matematika, 3(2), 122 - 140, doi: http://dx.doi.org/10.31100/histogram.v3i2.449

Permalink/DOI: http://dx.doi.org/10.31100/histogram.v3i2.449

\section{PENDAHULUAN}

Analisis data merupakan fase utama dalam proses penelitian karena setelah melalui serangkaian pengolahan data, maka peneliti dapat menarik kesimpulan dan membuat generalisasi kerangka konsep atau teori yang digunakannya (Suhartono, 2008). Di Perguruan Tinggi, mata kuliah Statistika Matematika membahas metoede statistik yang digunakan dalam pengolahan dan analisis data untuk memperoleh suatu kesimpulan yang akan berguna untuk pengambilan keputusan. Dengan memahami konsep Statistika, mahasiswa diharapkan dapat mengimplementasikan materi terhadap berbagai kasus dalam kehidupan nyata yang berkaitan dengan aplikasi statistik serta dapat memecahkan masalah 


\section{Histogram: Jurnal Pendidikan Matematika, 3 (2), 2019 - 123 Muhammad Taqwa, Akbar Taufik}

yang berhubungan dengan analisis data statistik. Proses analisis data untuk mengambil keputusan memiliki implementasi yang cukup luas dalam kehidu $\neg$ pan nyata, sehingga penelitian ini penting untuk dilaksanakan.

Selama ini banyak mahasiswa mengalami kesulitan dalam memahami konsep analisis data statistik. Kesulitan dan kekeliruan konsep yang biasa dialami mahasiswa antara lain mengenai uji yang digunakan dalam analisis data, ketidaktelitian dalam melakukan perhitungan analisis data dan ketepatan serta keakuratan solusi yang berakibat pada pengambilan kesimpulan. Di sisi lain, keterbatasan akses dengan sumber data di lapangan, baik secara langsung maupun tidak langsung, kurang memberikan dorongan motivasi kepada mahasiswa untuk belajar lebih mendalami persoalan analisis data yang dikaji. Akibatnya $>75 \%$ mahasiswa memperoleh hasil belajar yang kurang memuaskan (Hendikawati, 2016).

$\mathrm{R}$ merupakan bahasa program open source yang sangat berkembang pesat karena para pengguna $\mathrm{R}$ di seluruh dunia dapat memberikan kontribusi berupa kode, melaporkan bug, dan membuat dokumentasi, sehingga $\mathrm{R}$ akan dapat digunakan menganalisis data sesuai kasus dalam kehidupan nyata. Pembelajaran yang aspiratif didukung dengan buku ajar yang memanfaatkan software statistik, diharapkan dapat memotivasi mahasiswa dalam belajar menyelesaikan permasalahan yang diberikan dan mendorong mahasiswa untuk melakukan keterampilan proses belajar yang meningkatkan pemahaman (Setyawati: 2017). Merancang buku ajar yang ilustrasi, visualisasi dan simulatif langsung melalui software dalam pembelajaran statistika merupakan salah satu solusi yang dapat meningkatkan motivasi belajar dan pemahaman konsep dalam belajar statistika baik teori maupun aplikasi (Neumann, 2011).

Oleh sebab itu, dalam proses perkuliahan Statistika dipandang perlu disusun suatu buku ajar yang memanfaatkan software R sehingga menciptakan motivasi belajar dalam menganalisis data. Meningkatnya dorongan pada diri mahasiswa secara internal maupun eksternal untuk belajar secara mandiri dalam menghadapi kesulitan dalam analisis data yang berdampak pada meningkatkan pemahaman konsep mahasiswa terhadap materi Statistika

Berdasarkan latar belakang tersebut, maka rumusan masalah dalam penelitian ini yaitu : (1) Bagaimana validitas isi dan reliabilitas buku ajar statistika dengan bantuan software R ?; (2) Bagaimana kepraktisan buku ajar statistika dengan bantuan software R ?; (3) Apakah ada peningkatan motivasi belajar mahasiswa sebelum diajar menggunakan buku statistika dengan bantuan software $\mathrm{R}$ dengan setelah diajar menggunakan buku 
statistika dengan bantuan software R? (4) Apakah ada peningkatan pemahaman konsep mahasiswa sebelum diajar menggunakan buku statistika dengan bantuan software $\mathrm{R}$ dengan setelah diajar menggunakan buku statistika dengan bantuan software R ?.

Tujuan yang ingin dicapai dalam penelitian ini adalah dihasilkannya sebuah produk buku ajar Statistika dengan software $\mathrm{R}$ yang valid dan praktis dan dapat meningkatkan motivasi belajar dan pemahaman konsep mahasiswa. Buku ajar yang dikembangkan, dirancang agar mahasiswa dapat memahami konsep ilmu sambil praktikum langsung kasus nyata dengan software R sehingga menimbulkan motivasi belajar dan memberikan solusi akurat dalam kesulitan analisis data.

\section{METODE PENELITIAN}

\section{A. Jenis Penelitian}

Jenis penelitian ini adalah penelitian pengembangan yakni pengembangan buku ajar statistika dengan software $\mathrm{R}$ untuk meningkatkan motivasi belajar dan pemahaman konsep mahasiswa

\section{B. Waktu dan Lokasi Penelitian}

Penelitian ini akan dilaksanakan pada semester genap tahun ajaran 2018/2019 pada program studi Pendidikan Matematika STKIP Andi Matappa yang beralamat di Jl. A. Mauraga No.70 Pangkajene Kabupaten Pangkep Sulawesi Selatan.

\section{Subjek penelitian}

Subjek penelitian adalah mahasiswa semester IV yang memprogram mata kuliah Statistika Matematika pada program studi Pendidikan Matematika STKIP Andi Matappa.

\section{Instrumen Penelitian}

Instrumen-instrumen dalam penelitian ini adalah: (1) lembar validasi buku ajar, 2) lembar kepraktisan buku ajar, (3) angket motivasi belajar mahasiswa, dan (4) tes yang mengukur pemahaman konsep mahasiswa pada materi Statistika. Uraian dari keempat instrumen yang dikembangkan sebagai berikut:

\section{Lembar Validasi Buku Ajar}

Lembar validasi digunakan untuk memperoleh informasi tentang kualitas buku ajar berdasarkan penilaian para ahli di bidang statistika. Lembar validasi disusun berdasarkan 10 indikator kualitas buku ajar yang dijabarkan menjadi beberapa pertanyaan dan digunakan sebagai masukan dalam merevisi buku ajar yang telah dikembangkan. 


\section{Lembar Kepraktisan Buku Ajar}

Lembar uji kepraktisan terdiri dari 13 butir penyataan berdasarkan indikator kepraktisan buku ajar

3. Angket Motivasi Belajar Mahasiswa

Angket yang diberikan telah disusun dan direvisi berdasarkan validasi ahli dan praktisi berupa pernyataan sebelum dan sesudah diberi buku ajar yang terdiri atas soal pilihan ganda sebanyak 10 butir berdasarkan indikator motivasi belajar.

4. Tes Pemahaman Konsep Mahasiswa

Tes yang diberikan telah disusun dan direvisi berdasarkan validasi ahli dan praktisi berupa soal pretest dan posttest yang terdiri atas soal uraian sebanyak 6 butir berdasarkan indikator pemahaman konsep.

\section{E. Teknik Pengumpulan Data}

Untuk mengumpulkan data yang dikumpulkan dalam penelitian ini dilakukan dengan cara sebagai berikut: (1) Data hasil validasi ahli, (2) Data hasil kepraktisan buku ajar, (3) Data hasil motivasi belajar mahasiswa, (4) Data hasil pemahaman konsep mahasiswa

\section{F. Teknik Analisis Data}

1. Analisis Data Kevalidan Buku Ajar

Validitas isi dan reliabilitas menyeluruh dari suatu tes melalui penilaian pakar digunakan validitas isi Gregory (Ruslan, 2009). Kriteria hasil penilaian dari kedua validator minimal memiliki "relevansi kuat". Jika hasil dari koefisian validitas isi ini tinggi (V > $75 \%$ ), maka dapat dinyatakan bahwa hasil pengukuran atau interfensi yang dilakukan adalah sahih

\section{Analisis Data Kepraktisan Buku Ajar}

Kategori kepraktisan buku ajar oleh mahasiswa, digunakan konversi data berdasarkan kriteria yang disajikan dalam tabel berikut

Tabel 1. Kriteria Kepraktisan Buku Ajar

\begin{tabular}{ccc}
\hline No & Interval Total Skor & Kategori \\
\hline 1 & $\frac{5}{6} \cdot 5 \cdot 12 \cdot 14<X \leq 1.5 \cdot m \cdot n$ & Sangat Praktis \\
\hline 2 & $\frac{4}{6} \cdot 5 \cdot m \cdot n<X \leq \frac{5}{6} \cdot 5 \cdot m \cdot n$ & Praktis \\
\hline 3 & $\frac{3}{6} \cdot 5 \cdot m \cdot n<X \leq \frac{4}{6} \cdot 5 \cdot m \cdot n$ & Cukup Praktis \\
\hline
\end{tabular}


Histogram: Jurnal Pendidikan Matematika, 3 (2), 2019 - 126

Muhammad Taqwa, Akbar Taufik

\begin{tabular}{ccc}
\hline No & Interval Total Skor & Kategori \\
\hline 4 & $\frac{2}{6} \cdot 5 \cdot m \cdot n<X \leq \frac{3}{6} \cdot 5 \cdot m \cdot n$ & Kurang Praktis \\
\hline 5 & $\frac{1}{6} \cdot 5 \cdot m \cdot n<X \leq \frac{2}{6} \cdot 5 \cdot m \cdot n$ & Tidak Praktis
\end{tabular}

Keterangan : $\mathrm{m}=$ banyak pertanyaan; $\mathrm{n}=$ banyak mahasiswa; $\mathrm{X}=$ total skor

(Sumber : Khomsiatun, Retnawati, Tahun: 2015)

3. Analisis Data Motivasi Belajar Mahasiswa dan Pemahaman Konsep Mahasiswa

Untuk menganalisis apakah terdapat peningkatan yakni dengan menganalisis pretest dan posttest motivasi belajar dan pemahaman konsep dengan menggunakan uji ngain dengan rumus sebagai berikut:

$$
\text { Indeks ngain }=\frac{\text { skor } \text { posttest }- \text { skor pretest }}{\text { SMI }- \text { skor pretest }}
$$

\section{G. Bagan Alir Penelitian}

Berikut adalah gambaran bagan alir pengembangan buku ajar menggunakan model 4D Thiagarajan yang akan digunakan dalam penelitian ini yang terdiri dari 4 tahap yaitu: pendefinisian (define), perancangan (design), pengembangan (Develope) dan penyebaran (disseminate).

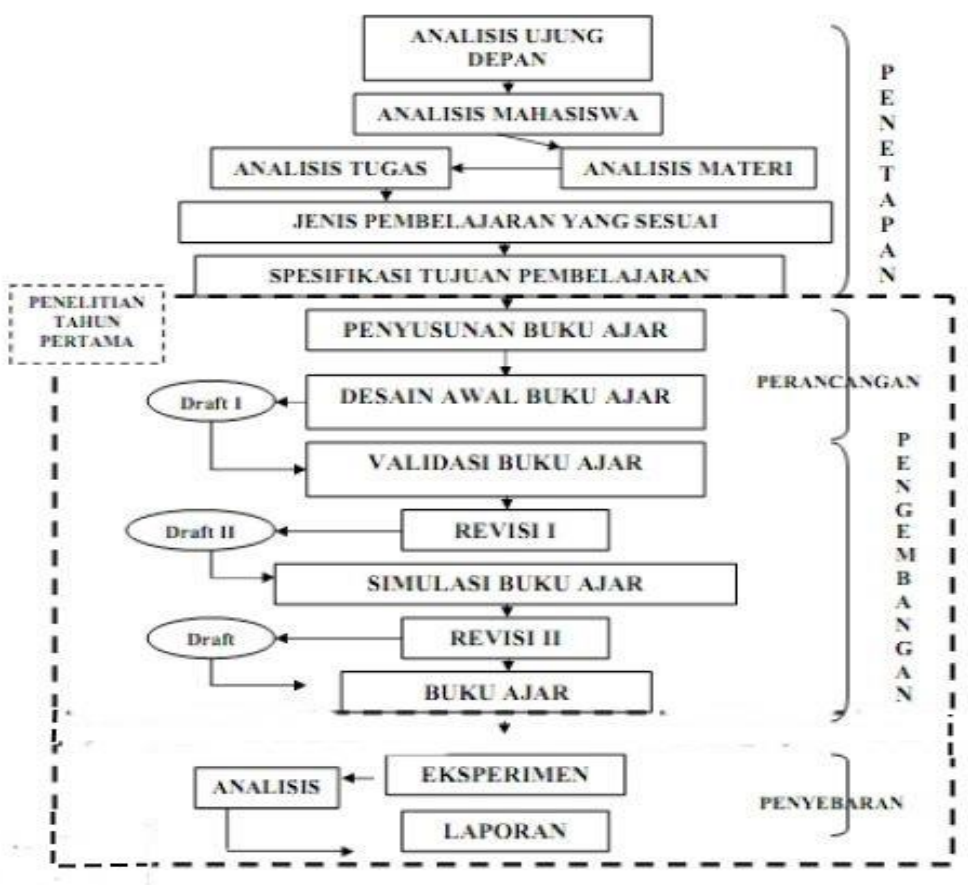

Gambar 1. Bagan Alir Penelitian Pengembangan Model 4D 


\section{HASIL DAN PEMBAHASAN}

Buku ajar yang telah disusun pada tahap awal penelitian (Draft 1), kemudian diuji melalui beberapa tahapan. Tahap pertama adalah uji validitasi buku ajar dengan menggunakan penilaian validitas ahli. Validitas buku ajar yang dinilai adalah mengenai validitas isi berkaitan dengan (a) aspek pendekatan penulisan; (b) aspek kebenaran konsep; (c) aspek kedalaman konsep; (d) aspek keluasan konsep; (e) aspek kejelasan kalimat; (f) aspek kebahasaan; (g) aspek evaluasi belajar; (h) aspek kegiatan mahasiswa / percobaan; (i) aspek keterlaksanaan; (j) aspek penampilan fisik; dan (k) pustaka acuan. Setelah melalui tahap validasi ahli selanjutnya dilakukan revisi pertama terhadap draft buku ajar dengan menyesuaikan dengan penilaian dari para ahli sehingga menghasilkan buku ajar Statistika Draft 2. Selanjutnya Draft 2 buku ajar diujikan secara terbatas kepada mahasiswa untuk menguji kepraktisan buku. Tahap selanjutnya, dengan hasil penilaian uji kepraktisan buku dilakukan revisi lebih lanjut dan buku ajar diperbaiki menjadi buku ajar Draft 3. Buku ajar Draft 3 ini kemudian diujikan pada mahasiswa dalam matakuliah statistika matematika.

\section{A. Analisis Validitas Buku Ajar}

Dari hasil implementasi, buku ajar terlebih dahulu divalidasi oleh dua orang ahli pakar untuk melihat validitas isi dan reliabilitas instrumen tersebut. ditunjukkan pada Tabel 2 berikut :

Tabel 2. Hasil Validasi Isi Buku Ajar

\begin{tabular}{llcc}
\hline \multirow{2}{*}{ No } & \multicolumn{1}{c}{ Aspek Yang Dinilai } & \multicolumn{2}{c}{ Validator } \\
\cline { 3 - 4 } & & I & II \\
\hline 1 & Menekankan keterampilan proses & 4 & 4 \\
\hline 2 & Menghubungkan ilmu pengetahuan dan teknologi dengan kehidupan & 3 & 4 \\
\hline 3 & Mengajak mahasiswa aktif dalam pembelajaran & 3 & 4 \\
\hline 4 & Kesesuaian konsep dengan konsep yang dikemukakan oleh ahli & 3 & 4 \\
& statistika & & \\
\hline 5 & Kebenaran susunan materi tiap bab dan prasyarat yang digunakan & 3 & 4 \\
\hline 6 & Muatan latar belakang sejarah penemuan konsep, hukum, atau fakta & 2 & 2 \\
\hline 7 & Kedalaman materi sesuai dengan kompetensi mahasiswa berdasarkan & 2 & 3 \\
& Kurikulum & & \\
\hline 8 & Kesesuaian konsep dengan materi pokok dalam Kurikulum & 2 & 3 \\
\hline 9 & Hubungan konsep dengan kehidupan sehari-hari & 3 & 4 \\
\hline 10 & Informasi yang dikemukakan mengikuti perkembangan zaman & 3 & 3 \\
\hline
\end{tabular}


Histogram: Jurnal Pendidikan Matematika, 3 (2), 2019 - 128

Muhammad Taqwa, Akbar Taufik

\begin{tabular}{|c|c|c|c|}
\hline \multirow{2}{*}{ No } & \multirow{2}{*}{ Aspek Yang Dinilai } & \multicolumn{2}{|c|}{ Validator } \\
\hline & & $\mathbf{I}$ & II \\
\hline 11 & Kalimat tidak menimbulkan makna ganda & 3 & 4 \\
\hline 12 & Kalimat yang digunakan mudah dipahami & 3 & 3 \\
\hline 13 & Bahasa yang digunakan mengajak mahasiswa interaktif & 3 & 4 \\
\hline 14 & Bahasa yang digunakan baku dan menarik & 3 & 4 \\
\hline 15 & Mengukur kemampuan kognitif, afektif, dan psikomotorik & 3 & 3 \\
\hline 16 & $\begin{array}{l}\text { Mengukur kemampuan mahasiswa secara mendalam dan } \\
\text { berdasarkan standar kompetensi yang ditentukan oleh Kurikulum }\end{array}$ & 2 & 3 \\
\hline 17 & Materi pokok sesuai dengan alokasi waktu di kampus & 4 & 4 \\
\hline 18 & Kegiatan mahasiswa / percobaan statistika dapat dilaksanakan & 3 & 4 \\
\hline 19 & Memberikan pengalaman langsung & 3 & 4 \\
\hline 20 & Mendorong mahasiswa menyimpulkan konsep, hukum atau fakta & 2 & 3 \\
\hline 21 & $\begin{array}{l}\text { Kesesuaian kegiatan mahasiswa / percobaan statistika dengan materi } \\
\text { pokok Kurikulum }\end{array}$ & 4 & 4 \\
\hline 22 & $\begin{array}{l}\text { Desain yang meliputi konsistensi, format, organisasi, dan daya tarik } \\
\text { buku baik }\end{array}$ & 4 & 3 \\
\hline 23 & Kejelasan tulisan dan gambar & 4 & 3 \\
\hline 24 & Penampilan fisik buku dapat mendorong minat baca mahasiswa & 3 & 3 \\
\hline 25 & Menggunakan Pustaka Acuan yang terbaru & 4 & 4 \\
\hline 26 & Susunan Penulis pustaka acuan yang akurat & 4 & 4 \\
\hline
\end{tabular}

(Sumber: Data Primer, Tahun: 2019)

$$
\begin{aligned}
& \text { Validitas isi }=\frac{D}{A+B+C+D}=\frac{21}{26}=0,81 \\
& \text { Reliabilitas }=\frac{2 D}{B+C+2 D}=\frac{42}{47}=0,89
\end{aligned}
$$

Hasil analisis validitas isi buku ajar menunjukkan skor validitas isi adalah 0,81 yang berarti bahwa validitas isi buku ajar termasuk kategori tinggi dengan reliabilitas 0,89 . Dengan demikian buku ajar layak untuk digunakan sebagai alat penunjang kegiatan pembelajaran statistika. 


\section{B. Analisis Kepraktisan}

Penilaian buku ajar oleh mahasiswa ditunjukkan pada Tabel 3:

Tabel 3. Rangkuman Penilaian Kepraktisan Buku Ajar oleh Mahasiswa

\begin{tabular}{lccccccccccccccc}
\hline Produk & $\mathbf{1}$ & $\mathbf{2}$ & $\mathbf{3}$ & $\mathbf{4}$ & $\mathbf{5}$ & $\mathbf{6}$ & $\mathbf{7}$ & $\mathbf{8}$ & $\mathbf{9}$ & $\mathbf{1 0}$ & $\mathbf{1 1}$ & $\mathbf{1 2}$ & $\mathbf{1 3}$ & $\mathbf{1 4}$ & Total \\
\hline Buku & 57 & 56 & 58 & 55 & 58 & 58 & 57 & 57 & 58 & 59 & 57 & 59 & 56 & 58 & 803 \\
Ajar & & & & & & & & & & & & & & &
\end{tabular}

(Sumber: Data Primer, Tahun: 2019)

Untuk menentukan kategorisasi kepraktisan buku ajar oleh mahasiswa digunakan konversi data berdasarkan kriteria yang disajikan dalam Tabel 4 berikut :

Tabel 4. Kriteria Kepraktisan Buku Ajar

\begin{tabular}{ccc}
\hline No & Interval Total Skor & Kategori \\
\hline 1 & $758<X \leq 910$ & Sangat Praktis \\
\hline 2 & $607<X \leq 758$ & Praktis \\
\hline 3 & $455<X \leq 607$ & Cukup Praktis \\
\hline 4 & $303<X \leq 455$ & Kurang Praktis \\
\hline 5 & $152<X \leq 303$ & Tidak Praktis \\
\hline
\end{tabular}

(Sumber: Data Primer, Tahun: 2019)

Hasil penilaian oleh mahasiswa menunjukkan bahwa total skor adalah 803 sehingga buku ajar termasuk dalam kategori "sangat praktis" sehingga buku ajar layak digunakan.

\section{Analisis Motivasi Belajar Mahasiswa}

1. Analisis Deskriptif

a. Pretest Motivasi Belajar Mahasiswa

Data pretest motivasi belajar mahasiswa yang berskala ordinal diubah menjadi skala interval dengan cara metode suksesif interval (MSI) menggunakan software $\mathrm{R}$ sehingga menghasilkan nilai statistika deskriptif sebagai gambar berikut :

$\begin{array}{lr}\text { nobs } & \text { Pretest } \\ \text { NAs } & 14.000000 \\ \text { Minimum } & 0.000000 \\ \text { Maximum } & 30.511370 \\ \text { 1. Quartile } & 47.859738 \\ \text { 3. Quartile } & 36.422912 \\ \text { Mean } & 38.904341 \\ \text { Median } & 37.772456 \\ \text { Sum } & 37.498886 \\ \text { SE Mean } & 528.814378 \\ \text { LCL Mean } & 1.076097 \\ \text { UCL Mean } & 35.447688 \\ \text { Variance } & 40.097223 \\ \text { Stdev } & 16.211800 \\ \text { Skewness } & 4.026388 \\ \text { Kurtosis } & 0.650736 \\ & 0.752738\end{array}$

Gambar 2. Output Statistika Deskriptif Pretest Motivasi Belajar Mahasiswa 
Berdasarkan gambar 2 terlihat bahwa nilai rata-rata pretest motivasi belajar adalah 37,77 dari skor ideal 49,06, dan standar deviasinya 4,03. Karena nilai standar deviasi relatif kecil, maka penyebaran data homogen, hal ini terlihat dalam gambar histogram berikut :

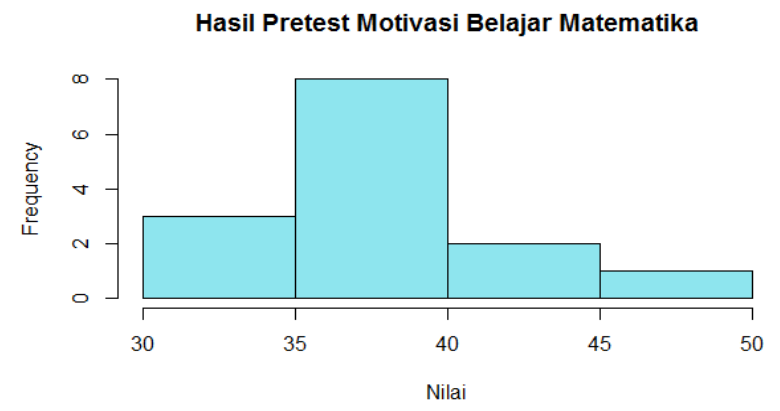

Gambar 3. Histogram Pretest Motivasi Belajar Mahasiswa

Dari gambar 3 terlihat bahwa penyebaran persentase penyebaran data pretest motivasi belajar mahasiswa yaitu pada interval 30 - 35 sebesar 21,43\%, 35 - 40 sebesar $57,15 \%, 40-45$ sebesar $14,28 \%$, dan $45-50$ sebanyak 7,14\%. Terlihat bahwa sebagian besar data tersebar di interval 35 - 40 yang memuat rata - rata pretest motivasi belajar 37,77 dengan standar deviasi 4,06.

b. Posttest Motivasi Belajar Mahasiswa

Data posttest motivasi belajar mahasiswa yang berskala ordinal diubah menjadi skala interval dengan cara metode suksesif interval (MSI) dianalisis dengan menggunakan software R dan menghasilkan nilai statistika deskriptif sebagai berikut :

$\begin{array}{lr}\text { nobs } \quad \text { Posttest } & \\ \text { NAs } & 14.000000 \\ \text { Minimum } & 0.000000 \\ \text { Maximum } & 30.379029 \\ \text { 1. Quartile } & 46.549481 \\ \text { 3. Quartile } & 36.822735 \\ \text { Mean } & 39.413918 \\ \text { Median } & 37.772458 \\ \text { Sum } & 38.143547 \\ \text { SE Mean } & 528.814408 \\ \text { LCL Mean } & 1.022138 \\ \text { UCL Mean } & 35.564263 \\ \text { Variance } & 39.980652 \\ \text { Stdev } & 14.626718 \\ \text { Skewness } & 3.824489 \\ \text { Kurtosis } & 0.190726 \\ & 0.277167\end{array}$

Gambar 4. Output Statistika Deskriptif Posttest Motivasi Belajar Mahasiswa

Berdasarkan gambar 4 terlihat bahwa nilai rata-rata posttest motivasi belajar adalah 37,77 dari skor ideal 47,95, dan standar deviasinya 3,82. Karena nilai standar deviasi relatif kecil, maka penyebaran data homogen, hal ini terlihat dalam gambar histogram berikut : 


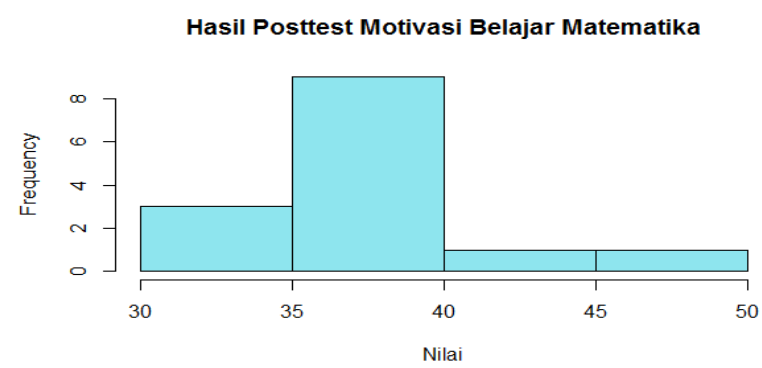

Gambar 5. Histogram Posttest Motivasi Belajar Mahasiswa

Dari gambar 5 terlihat bahwa penyebaran persentase penyebaran data posttest motivasi belajar mahasiswa yaitu pada interval 30 - 35 sebesar 21,43\%, 35 - 40 sebesar $64,29 \%, 40-45$ sebesar 7,14\%, dan $45-50$ sebanyak 7,14\%. Terlihat bahwa sebagian besar data tersebar di interval 35 - 40 yang memuat rata - rata posttest motivasi belajar 37,77 dengan standar deviasi 3,82.

2. Analisis Inferensial

a. Uji Normalitas

Untuk lebih jelasnya hasil uji normalitas tersebut disajikan dalam gambar berikut:

$\begin{array}{ll}\text { Shapiro-wilk normality test } & \text { Shapiro-wilk normality test } \\ \text { data: nonparametrik\$Pretest } & \text { data: nonparametrik\$Posttest } \\ W=0.93064, \text { p-value }=0.3115 & W=0.94025, \text { p-value }=0.4215\end{array}$

Gambar 6. Uji Normalitas Pretest dan Posttest Motivasi Belajar Mahasiswa

Hasil analisis nilai prestest untuk motivasi belajar mahasiswa menunjukkan nilai $p$ $>\alpha$ yaitu $0,3115>0,05$, sedangkan hasil nilai posttest untuk motivasi belajar mahasiswa menunjukkan nilai $p>\alpha$ yaitu $0,4215>0,05$. Hal ini menunjukkan bahwa nilai pretest dan posttest untuk motivasi belajar termasuk kategori normal.

b. Uji Homogenitas

Untuk lebih jelasnya hasil uji homogenitas tersebut disajikan dalam gambar berikut berikut:

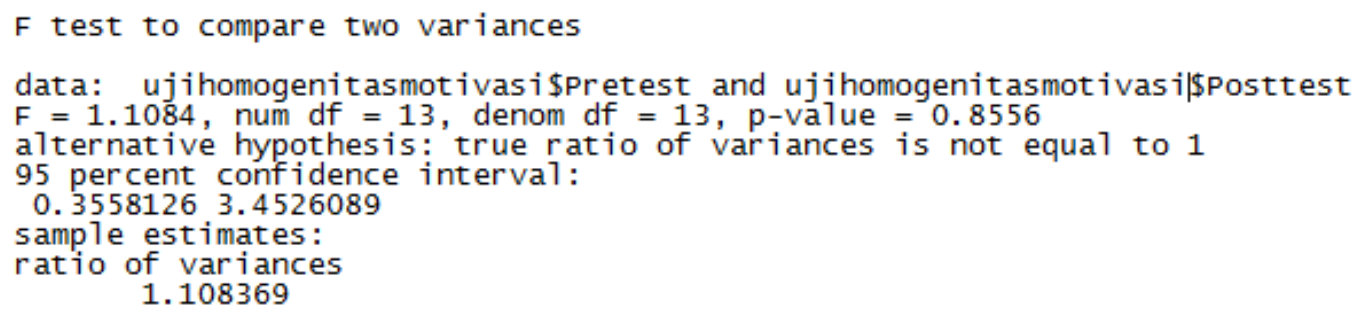

Gambar 7. Uji Homogenitas Motivasi Belajar Mahasiswa 


\section{Histogram: Jurnal Pendidikan Matematika, 3 (2), 2019 - 132 Muhammad Taqwa, Akbar Taufik}

Hasil perhitungan untuk motivasi belajar adalah nilai $p>\alpha$ yaitu $0,856>0,05$. Kriteria pengujiannya adalah nilai kedua sampel sama jika nilai $p>\alpha$. Jadi dapat disimpulkan bahwa kedua sampel memiliki nilai varian yang sama.

c. Uji Hipotesis

Uji prasyarat uji t diketahui bahwa populasi pretest dan posttest motivasi belajar mahasiswa berdistribusi normal dan memiliki varians yang sama maka dilakukan pengujian hipotesis seperti gambar berikut:

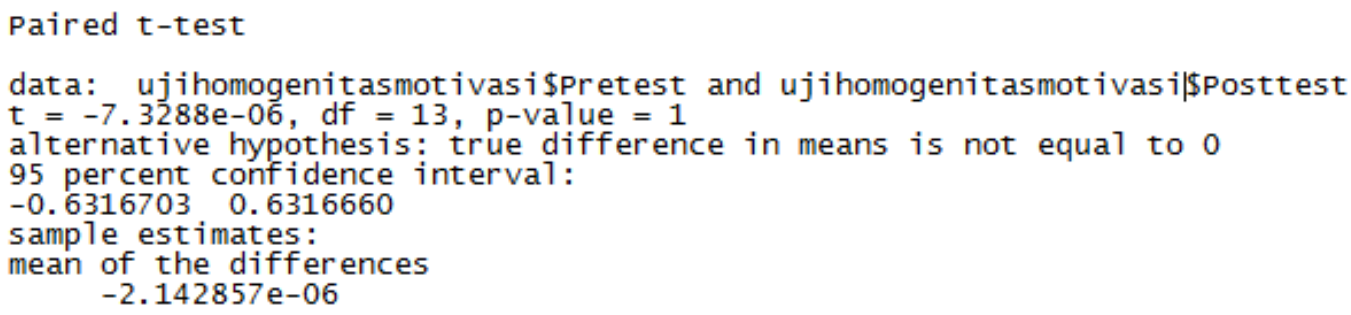

Gambar 8. Uji t Berpasangan Motivasi Belajar Mahasiswa

Hasil analisis diatas diperoleh nilai $\mathrm{t}$ hitung $=-7.32 e^{-6}<\mathrm{t}$ tabel $=-1.77$ atau $p=1$ $>\alpha=0,05$ maka dapat disimpulkan cukup bukti untuk menerima $\mathrm{H}_{0}$, sehingga berdasarkan data tersebut, setelah diberi perlakuan diajar menggunakan software $\mathrm{R}$ dan buku ajar statistika dengan $\mathrm{R}$, rata-rata motivasi belajar mahasiswa akan sama dengan tingkat kepercayaan 95\%, dapat disimpulkan bahwa tidak peningkatan motivasi belajar mahasiswa pada matakuliah statistika matematika dengan perlakuan diajar menggunakan software $\mathrm{R}$ dan buku ajar statistika dengan $\mathrm{R}$.

\section{d. Uji N Gain}

Uji t yang menyimpulkan bahwa tidak peningkatan motivasi belajar mahasiswa pada matakuliah statistika matematika dengan perlakuan diajar menggunakan software $\mathrm{R}$ dan buku ajar statistika dengan $\mathrm{R}$, hal ini dapat terlihat dari nilai ngain tiap item motivasi belajar mahasiswa yang umumnya berada pada kategori rendah, dan digambarkan pada gambar berikut :

Nilai Ngain tiap item

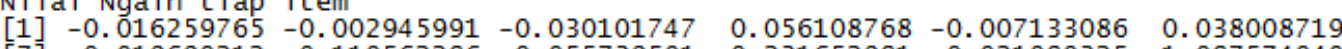

$\left[\begin{array}{llllllll}77] & 0.019690212 & -0.110562286 & 0.055739501 & 0.231652981 & -0.021080325 & -1.087574040\end{array}\right.$

[13] $-0.162060353 \quad 0.008090283$

Rata-rata ngain

[1] -0.07345908

Gambar 9. Output Uji Ngain Item Motivasi Belajar Mahasiswa

Berdasarkan gambar 9, rata-rata ngain item motivasi belajar mahasiswa diperoleh nilai $-0,07$ berada pada kategori rendah. 


\section{Analisis Pemahaman Konsep Mahasiswa}

1. Analisis Deskriptif

a. Pretest Pemahaman Konsep Mahasiswa

Data pretest pemahaman konsep mahasiswa dianalisis dengan menggunakan software R dan menghasilkan nilai statistika deskriptif sebagai gambar berikut :

\begin{tabular}{lr} 
& \multicolumn{1}{c}{ Pretest } \\
nobs & 14.000000 \\
NAs & 0.000000 \\
Minimum & 16.666667 \\
Maximum & 66.666667 \\
1. Quartile & 33.333333 \\
3. Quartile & 50.000000 \\
Mean & 44.047619 \\
Median & 50.000000 \\
Sum & 616.666667 \\
SE Mean & 3.750109 \\
LCL Mean & 35.946001 \\
UCL Mean & 52.149237 \\
Variance & 196.886447 \\
Stdev & 14.031623 \\
Skewness & -0.058629 \\
Kurtosis & -0.864362
\end{tabular}

Gambar 10. Output Statistika Deskriptif Pretest Pemahaman Konsep Mahasiswa

Berdasarkan gambar 10, terlihat bahwa nilai rata-rata pretest pemahaman konsep mahasiswa adalah 44,05 dari skor ideal 100, dan standar deviasinya 14,03. Karena nilai standar deviasi relatif besar, maka penyebaran data beragam, hal ini terlihat dalam gambar histogram berikut :

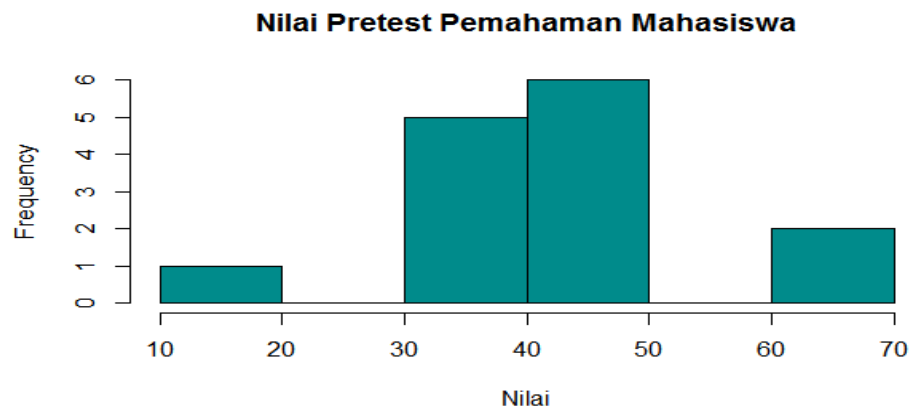

Gambar 11. Histogram Pretest Pemahaman Konsep Mahasiswa

Dari gambar 11 terlihat bahwa penyebaran persentase penyebaran data pretest motivasi belajar mahasiswa yaitu pada interval 30 - 35 sebesar 7,14\%, 30 - 40 sebesar $35,71 \%, 40-50$ sebesar $42,87 \%$, dan $60-70$ sebanyak $14,28 \%$. Terlihat bahwa sebagian besar data tersebar di interval 40 - 50 yang memuat rata - rata pretest pemahaman konsep mahasiswa 44,05 dengan standar deviasi 14,03.

b. Posttest Pemahaman Konsep Mahasiswa

Data posttest pemahaman konsep mahasiswa dianalisis dengan menggunakan software $\mathrm{R}$ dan menghasilkan nilai statistika deskriptif sebagai berikut : 
Histogram: Jurnal Pendidikan Matematika, 3 (2), 2019 - 134

Muhammad Taqwa, Akbar Taufik

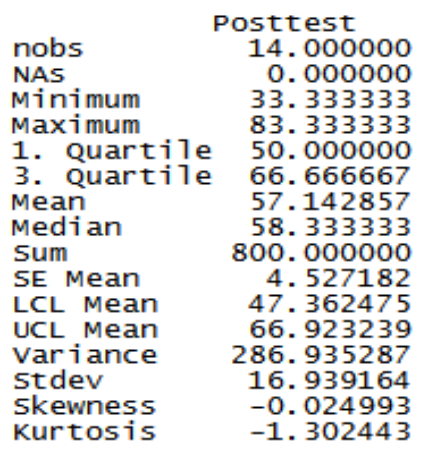

Gambar 12. Output Statistika Deskriptif Posttest Pemahaman Konsep Mahasiswa

Berdasarkan gambar 12 terlihat bahwa nilai rata-rata posttest pemahaman konsep mahasiswa adalah 57,14 dari skor ideal 100, dan standar deviasinya 16,93. Karena nilai standar deviasi relatif besar, maka penyebaran data beragam, hal ini terlihat dalam gambar histogram berikut :

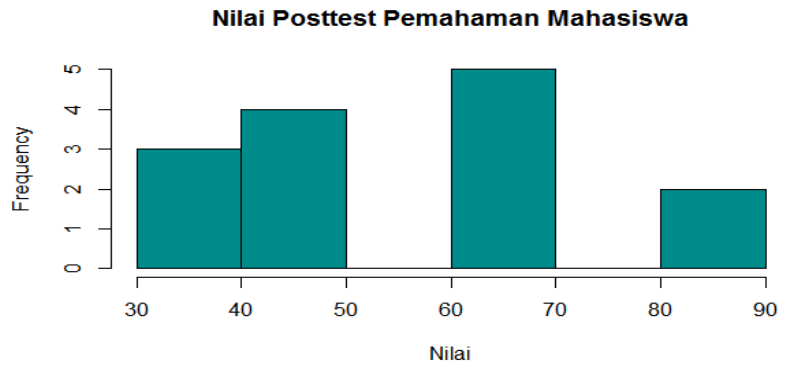

Gambar 13. Histogram Posttest Pemahaman Konsep Mahasiswa

Dari gambar 13 terlihat bahwa penyebaran persentase penyebaran data posttest motivasi belajar mahasiswa yaitu pada interval 30 - 40 sebesar 21,43\%, 40 - 50 sebesar $28,57 \%, 60$ - 70 sebesar $35,71 \%$, dan 80 - 90 sebanayak $14,29 \%$.

2. Analisis Infrensial

a. Uji Normalitas

Untuk lebih jelasnya hasil uji normalitas tersebut disajikan dalam gambar berikut berikut:

Shapiro-wilk normality test

data: pretestpemahaman\$Pretest

$\mathrm{W}=0.88898, \mathrm{p}$-value $=0.07813$

\section{Shapiro-wilk normality test \\ data: posttespemahaman\$Posttest $\mathrm{W}=0.89337, \mathrm{p}$-value $=0.09041$}

Gambar 14. Uji Normalitas Pretest dan Posttest Pemahaman Konsep Mahasiswa 
Hasil analisis nilai prestest untuk pemahaman konsep mahasiswa menunjukkan nilai $p>\alpha$ yaitu $0,08>0,05$, sedangkan hasil nilai posttest untuk pemahaman konsep mahasiswa menunjukkan nilai $p>\alpha$ yaitu $0,09>0,05$. Hal ini menunjukkan bahwa nilai pretest dan posttest untuk pemahaman konsep mahasiswa termasuk kategori normal.

b. Uji Homogenitas

Untuk lebih jelasnya hasil uji homogenitas tersebut disajikan dalam gambar berikut berikut:

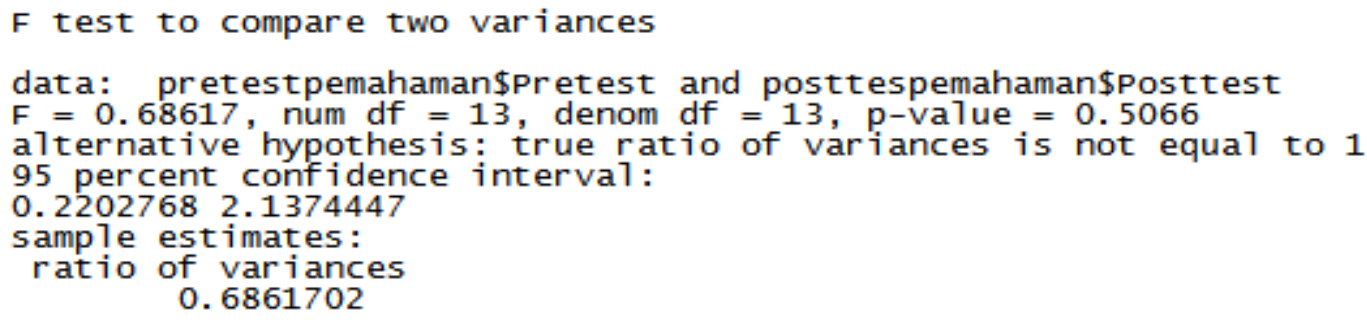

Gambar 15. Uji Homogenitas Pemahaman Konsep Mahasiswa

Hasil perhitungan untuk motivasi belajar adalah nilai $p>\alpha$ yaitu 0,51 $>0,05$. Kriteria pengujiannya adalah nilai kedua sampel sama jika nilai $p>\alpha$. Jadi dapat disimpulkan bahwa kedua sampel memiliki nilai varian yang sama.

c. Uji Hipotesis

Uji prasyarat uji t diketahui bahwa populasi pretest dan posttest pemahaman konsep mahasiswa berdistribusi normal dan memiliki varians yang sama maka dilakukan pengujian hipotesis seperti gambar berikut:

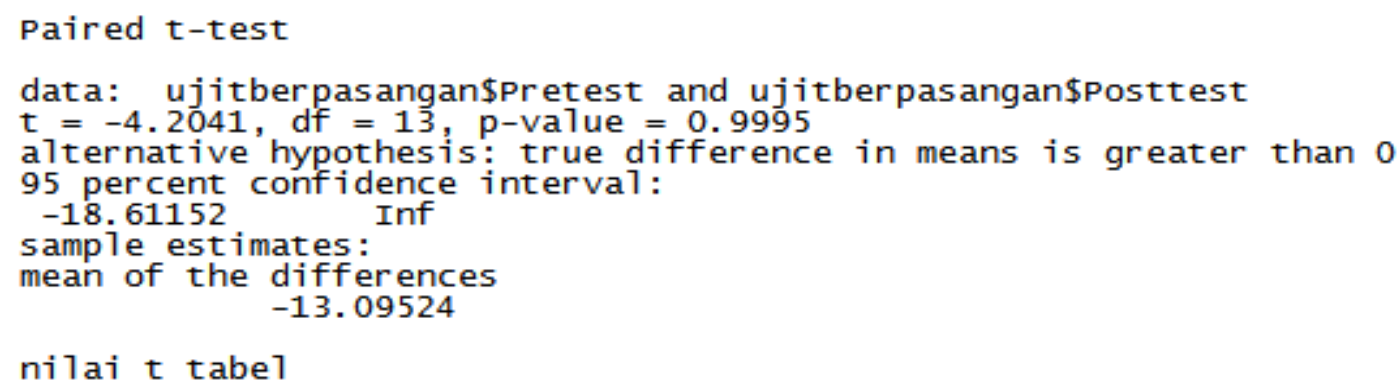

Gambar 16. Uji t Berpasangan Pemahaman Konsep Mahasiswa

Hasil analisis diatas diperoleh nilai $\mathrm{t}$ hitung $=-4.20<\mathrm{t}$ tabel $=-1.77$ atau $\mathrm{p}=0,99$ $>\alpha=0,05$ maka dapat disimpulkan cukup bukti untuk menerima $\mathrm{H}_{0}$. Sehingga berdasarkan data tersebut, setelah diberi perlakuan diajar menggunakan software $\mathrm{R}$ dan buku ajar statistika dengan $\mathrm{R}$, rata-rata pemahaman konsep mahasiswa akan sama dengan tingkat 
kepercayaan 95\%, dapat disimpulkan bahwa tidak ada peningkatan pemahaman konsep mahasiswa pada matakuliah statistika matematika dengan perlakuan diajar menggunakan software R dan buku ajar statistika dengan R.

\section{d. Uji NGain}

Dari uji t yang menyimpulkan bahwa tidak ada peningkatan pemahaman konsep mahasiswa pada matakuliah statistika matematika dengan perlakuan diajar menggunakan software $\mathrm{R}$ dan buku ajar statistika dengan $\mathrm{R}$, hal ini dapat terlihat dari nilai ngain tiap item pemahaman konsep mahasiswa yang umumnya berada pada kategori rendah, dan digambarkan pada gambar berikut :

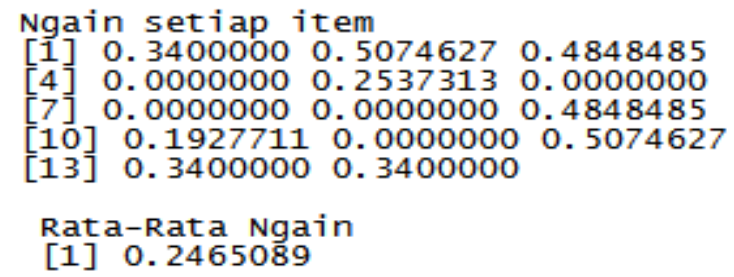

Gambar 17. Output Uji Ngain Item Motivasi Belajar Mahasiswa

Berdasarkan gambar 17, rata-rata ngain item pemahaman konsep mahasiswa diperoleh nilai 0,25 berada pada kategori rendah.

\section{E. Pembahasan}

Jika ditinjau dari aspek validitas isi buku ajar menunjukkan validitas isi dan reliabilitas buku ajar termasuk kategori tinggi. Dengan demikian buku ajar layak untuk digunakan sebagai alat penunjang kegiatan pembelajaran statistika. Kevalidan sebuah media penting untuk diuji sebab kevalidan termasuk salah satu kriteria untuk menentukan sebuah media dikatakan baik. Media pembelajaran yang dikembangkan dapat dikatakan valid jika semua ahli yang memvalidasi menyatakan valid. Pendapat ini didukung oleh hasil penelitian Syahputra (2015) yang menyimpulkan bahwa media pembelajaran yang berkualitas dan layak digunakan jika telah memenuhi standar kevalidan yang dinilai oleh validator ahli.

Menurut Gazpers (2006) validasi desain dan pengembangan suatu produk harus dilakukan untuk menjamin bahwa produk yang dihasilkan sesuai dengan persyaratanpersyaratan penggunaan dari produk tersebut. Validasi desain dan pengembangan produk pada dasarnya untuk menegaskan bahwa produk akhir yang dihasilkan mampu memenuhi kebutuhan pelanggan, dalam penelitian ini adalah dosen dan mahasiswa, dibawah kondisikondisi tertentu. Penelitian Widyaningrum (2013), disebutkan bahwa produk yang 


\section{Histogram: Jurnal Pendidikan Matematika, 3 (2), 2019 - 137 Muhammad Taqwa, Akbar Taufik}

dikembangkan harus divalidasi agar dapat bermanfaat secara optimal bagi mahasiswa sebagai sasaran.

Jika ditinjau dari aspek kepraktisan oleh mahasiswa menunjukkan bahwa buku ajar termasuk dalam kategori "sangat praktis" sehingga buku ajar layak digunakan. Kepraktisan media merupakan salah satu faktor penting yang seharusnya ada dalam media pembelajaran yang dikembangkan. Nilai kepraktisan buku ajar ini didapatkan dari nilai aspek penerapan software $\mathrm{R}$ yang kemudian nilainya dirata-ratakan dengan nilai aspek yang lain. Kepraktisan media yang dikembangkan berbanding lurus dengan hasil penelitian Syahputra (2015) yang mengatakan media yang dikembangkan tergolong praktis ketika dapat diterapkan dalam proses pembelajaran dengan baik tanpa ada masalah yang dapat mengganggu proses pembelajaran. Media yang praktis mampu memudahkan dosen dan mahasiswa dalam menggunakannya. Media yang tidak praktis dapat menyebabkan para penggunanya malas dalam menggunakan media sehingga proses pembelajaran dapat tidak maksimal.

Jika ditinjau dari aspek motivasi belajar dan pemahaman konsep mahasiswa, kurang sejalan dengan tinjauan teoritis yang dikemukakan oleh Neumann (2011), bahwa merancang buku ajar yang ilustrasi, visualisasi dan simulatif langsung melalui software dalam pembelajaran statistika merupakan salah satu solusi yang dapat meningkatkan motivasi belajar dan pemahaman konsep dalam belajar statistika baik teori maupun aplikasi, hasil penelitian Adel (2017), bahwa buku dapat membantu dosen dalam meningkatkan motivasi dalam belajar, serta (Bien, dkk, 2019; Muhktar, 2013; Fitria, Arnawa dan Lufri, 2014, Nuranisa, Nu'man dan Arfinanti, 2015), bahwa buku ajar yang valid dan praktis dapat meningkatkan pemahaman konsep mahasiswa.

Buku ajar yang dikembangkan, dirancang agar mahasiswa dapat memahami konsep ilmu sambil praktikum langsung kasus nyata dengan software $\mathrm{R}$ ternyata tidak meningkatkan motivasi belajar dan pemahaman konsep mahasiswa secara signifikan. Untuk aspek motivasi belajar, ternyata patut diduga pengetikan rumus dengan koding cukup memberatkan mahasiswa terutama dalam menghafal rumus statistika, terlebih ini merupakan pengalaman pertama mahasiswa belajar dengan menggunakan koding. Hal ini sejalan dengan hasil penelitian Daly (2011) bahwa belajar koding membosankan dan waktu yang dibutuhkan untuk mengembangkan output yang sederhana sangat panjang, sehingga motivasi dalam belajar coding berkurang. Untuk aspek pemahaman konsep, ternyata patut diduga, kurangnya interaksi antar dosen dan mahasiswa secara langsung menjadi salah satu faktor sehingga pemahaman konsep mahasiswa tidak meningkat (Naufal, 2018). Jumlah 
sampel penelitian yang kurang banyak yaitu cuma 14 mahasiswa sekaligus menyulitkan pengambilan kesimpulan. Selain itu, faktor kemudahan mahasiswa menjawab soal pemahaman konsep yang berbentuk pilihan ganda yang memungkinkan mereka menebak jawaban ketika mengalami kesulitan (Sudjana, 2006) juga diduga mempengaruhi pemahaman konsep mahasiswa. Hal ini didukung dengan rata-rata ngain item motivasi belajar dan pemahaman konsep mahasiswa yang hanya pada kategori rendah.

\section{KESIMPULAN DAN SARAN}

\section{A. Kesimpulan}

Adapun kesimpulan dari penelitian ini yaitu (1) Validitas isi buku ajar termasuk kategori tinggi sehingga buku ajar layak untuk digunakan sebagai alat penunjang kegiatan pembelajaran statistika matematika; (2) Penilaian kepraktisan buku ajar oleh mahasiswa menunjukkan bahwa buku ajar termasuk dalam kategori "sangat praktis" sehingga buku ajar layak digunakan.; (3) Tidak ada peningkatan signifikan motivasi belajar mahasiswa pada matakuliah statistika matematika dengan perlakuan diajar menggunakan software $\mathrm{R}$ dan buku ajar statistika dengan R. Hal ini didukung oleh rata-rata ngain item motivasi belajar mahasiswa diperoleh nilai $-0,07$ berada pada kategori rendah; (4) Tidak ada peningkatan pemahaman konsep mahasiswa pada matakuliah statistika matematika dengan perlakuan diajar menggunakan software $\mathrm{R}$ dan buku ajar statistika dengan $\mathrm{R}$. Hal ini didukung oleh rata-rata ngain item pemahaman konsep mahasiswa diperoleh nilai 0,25 berada pada kategori rendah.

\section{B. Saran}

Adapun saran dari penelitian ini yaitu (1) perlu diperkenalkan matakuliah pemrograman komputer dalam pembelajaran sebelum diajar analisis data statistika dengan software R; (2) Buku Ajar diuji cobakan pada jumlah sampel penelitian yang besar; (d) tes pemahaman konsep dalam bentuk essay. 


\section{UCAPAN TERIMAKASIH}

Ucapan terimakasih diberikan kepada Direktorat Riset dan Pengabdian (DRP) Dirjen DIKTI yang memberikan bantuan dana kepada tim peneliti dalam memperlancar kegiatan penelitian ini melalui hibah desentralisasi Penelitian Dosen Pemula (PDP).

\section{DAFTAR PUSTAKA}

Adel, A, M. (2017). Motivasi Mahasiswa Terhadap Buku Kerja Kalkulus 1 Berbasis Konstruktivisme Pada Program Studi Pendidikan Matematika FKIP Ummy Solok. Jurnal Residu, 1(1), 1 - 7

Bien, Y, I., Daniel, F., Taneo, P, N, L. (2019). Pengembangan Buku Ajar Kalkulus Integral Berbasis Maple Untuk Meningkatkan Pemahaman Konsep Mahasiswa. ANARGYA: Jurnal Ilmiah Pendidikan Matematika, 2(1), 39 - 45

Daly, A, S. (2011). Determinants of Participating in Australian University Student Exchange Programs. Journal of Research in International Education 10(1):58-70

Fitria, M., Arnawa, M., Lufri. (2014). Pengembangan Modul Aljabar Linear Elementer bernuansa Konstruktivisme berbantuan ICT. Jurnal Eksakta, 1: 34-42.

Gaspersz, V. 2006. ISO 9001: (2000) And Continual Quality Improvement (Terjemahan Oleh Agustinus Purwanta). Jakarta: PT. Gramedia Pustaka Utama.

Hendikawati, P., \& Arini, F. Y. (2016). Pengembangan Buku Ajar Statistika Berbantuan Tik Dengan Pendekatan Penilaian Portofolio Untuk Meningkatkan Komunikasi Dan Koneksi Matematis. Jurnal Penelitian Pendidikan, 33(2), 163-174.

Khomsiatun, S., \& Retnawati, H. (2015). Pengembangan Perangkat Pembelajaran dengan Penemuan Terbimbing untuk Meningkatkan Kemampuan Pemecahan Masalah. Jurnal Riset Pendidikan Matematika, 2(1), 92-106..

Mukhtar. (2013). Pengembangan Bahan Ajar Matematika berbasis Masalah untuk Memfasilitasi Pencapaian Kemampuan Penalaran dan Pemahaman Konsep Siswa. Prosiding Semirata FMIPA Universitas Lampung FMIPA Unila, 353- 360.

Naufal, M, F. (2018). Analisa Teknik Pembelajaran dan Pengajaran Pemrograman pada Universitas dan Industri. Jurnal Informatika \& Multimedia, 10(2), 1 - 7

Neumann, D. L., Neumann, M. M., \& Hood, M. (2011). Evaluating Computer-Based Simulations, Multimedia and Animations that help Integrate Blended Learning with Lectures in First Year Statistics. Australasian Journal of Educational Technology, 27(2), 274-289

Nuranisa, R. A., Nu'man, M., Arfinanti, N. (2015). Pengembangan Bahan Ajar dengan Model Group Invesigation dalam Memfasilitasi Pemahaman Konsep Matematika. Seminar Nasional dan Pendidikan Matematika UNY, ISBN. 978-602-73403-0-5, 697-704.

Ruslan. (2009). Validitas Isi. Buletin Pa'biritta, 10(6), 18-19.

Setyawati, R, D., Albab, I, U., dan Endahwuri, D. (2017). Efektivitas Model Problem Based Learning Berbantuan Mobile Learning pada Mata Kuliah Matematika Ekonomi. Semarang: Laporan Penelitian Dosen Pemula Universitas PGRI Semarang.

Sudjana, Nana. (2006). Penilaian Hasil Belajar. Bandung: PT. Remaja Rosda Karya

Suhartono. (2008). Modul Perkuliahan Analisis Data Statistik dengan R. Surabaya: Jurusan Statistika ITS 
Histogram: Jurnal Pendidikan Matematika, 3 (2), 2019 - 140

Muhammad Taqwa, Akbar Taufik

Syahputra, E \& Rajagukguk, W. (2015). Pengembangan Media Pembelajaran Matematika Berbantuan Program Flash Untuk Meningkatkan Kemampuan Matematika Siswa SMP. Jurnal Tabularasa Pps Unimed. 12 (2), 44 - 54

Widyaningrum, R. (2013). Pengembangan Modul Berorientasi POE (Predict, Observe, Explain) Berwawasan Lingkungan pada Materi Pencemaran untuk Meningkatkan Hasil Belajar Siswa. Bioedukasi, 6 (1), 100 - 117 